\title{
Rancang Bangun Aplikasi Mobile Android Sistem Kehadiran Mahasiswa melalui Pencocokan Tanda Tangan Studi Kasus Jurusan Teknik Informatika ITS
}

\author{
Novita Retno P L, Sarwosri, dan Dwi Sunaryono \\ Departemen Informatika, Fakultas Teknologi Informasi, Institut Teknologi Sepuluh Nopember (ITS) \\ e-mail: sarwosri@if.its.ac.id
}

\begin{abstract}
Abstrak-Sistem kehadiran mahasiswa merupakan proses pencatatan kehadiran mahasiswa di kelas. Dengan adanya sistem kehadiran ini maka dapat membuktikan bahwa mahasiswa tersebut telah berada di dalam kelas. Pencatatan kehadiran mahasiswa dapat dilakukan dengan berbagai cara. Di Jurusan Teknik Informatika ITS, sistem kehadiran mahasiswa dilakukan secara manual yaitu melakukan tanda tangan di kertas daftar kehadiran kelas. Hal ini menimbulkan celah kelemahan yaitu terjadi kecurangan dalam pencatatan kehadiran atau disebut titip absen. Titip absen merupakan kejadian di mana mahasiswa tercatat hadir di daftar hadir kertas tetapi kenyataannya mahasiswa tersebut tidak hadir di kelas. Oleh karena itu, diperlukan suatu sistem yang dapat digunakan untuk mengatasi kecurangan tersebut. Tujuan dibangunnya aplikasi mobile ini sebagai studi yaitu membangun sistem pencatatan kehadiran online dengan pencocokan tanda tangan. Pencocokan tanda tangan dilakukan dengan cara mengambil fitur-fitur dari gambar tanda tangan kemudian menghitung jarak euclidean distance untuk mengetahui kecocokan tanda tangan. Kecocokan tanda tangan bernilai benar (sesuai) jika nilai euclidean distance kurang dari 0.89. Berdasarkan hasil percobaan tingkat akurasi yang didapat yaitu $65 \%$.
\end{abstract}

Kata Kunci-Euclidean distance, mobile application, normalisasi, pencocokan tanda tangan, sistem kehadiran.

\section{PENDAHULUAN}

$S_{\mathrm{s}}^{\mathrm{s}}$ ISTEM kehadiran mahasiswa merupakan proses pencatatan kehadiran mahasiswa di kelas. Dengan adanya sistem kehadiran ini maka dapat membuktikan bahwa mahasiswa tersebut telah berada di dalam kelas. Pencatatan kehadiran mahasiswa dapat dilakukan dengan berbagai cara. Di Jurusan Teknik Informatika ITS, sistem kehadiran mahasiswa dilakukan secara manual yaitu melakukan tanda tangan di kertas daftar kehadiran kelas. Hal ini menimbulkan celah kelemahan yaitu terjadi kecurangan dalam pencatatan kehadiran atau disebut titip absen. Titip absen merupakan kejadian di mana mahasiswa tercatat hadir di daftar hadir kertas tetapi kenyataannya mahasiswa tersebut tidak hadir di kelas. Dengan menggunakan sistem kehadiran manual, mahasiswa lain dapat melakukan tanda tangan untuk mahasiswa lain.

Perkembangan teknologi informasi di dunia semakin cepat, khususnya pada teknologi perangkat bergerak (mobile) dan internet. Hal ini diikuti dengan bertambahnya pengguna smartphone. Di Indonesia tercatat sebagai negara di Asia tenggara yang penduduk terbanyak menggunakan Android yaitu 41 juta pengguna atau 94\%, sedangkan pengguna iOS hanya 2,8 juta pengguna atau $6 \%$ [1].

Akses dan pengambilan informasi juga semakin mudah dan cepat diakses melalui penggunaan perangkat bergerak dan web. Proses validasi sudah banyak diterapkan seiring dengan perkembangan teknologi informasi misalnya sistem kehadiran dengan menggunakan alat fingerprint, sistem kehadiran menggunakan deteksi suara, dan lain-lain. Namun kelemahan dari penerapan yang sudah ada adalah kurangnya fleksibilitas dari penerapan yang ada dimana teknologi yang digunakan tidak bisa berpindah tempat dan diakses kapanpun. Oleh karena itu aplikasi ini mengimplementasikan sistem kehadiran berbasis Android dengan harapan mampu menambah fleksibilitas dari sistem kehadiran yang sudah ada saat ini. Aplikasi kehadiran yang akan dibuat akan dibatasi ruang lingkup penggunanya yaitu mahasiswa Teknik Informatika ITS. Hasil yang diharapkan dari pengerjaan aplikasi ini berupa aplikasi mobile yang menggantikan proses pencatatan kehadiran mahasiswa dari sistem manual melalui tanda tangan pada kertas daftar hadir kelas menjadi sistem online dengan metode pencocokan tanda tangan pada aplikasi mobile.

\section{TINJAUAN PUSTAKA}

Image preprocessing yang dilakukan di dalam aplikasi ini adalah melakukan $R G B$ to grayscale conversion dan melakukan cropping pada gambar tanda tangan. Sedangkan fitur yang digunakan adalah histogram horisontal maksimal, aspek rasio, piksel area, dan skewness.

\section{A. Normalisasi Skala}

Normalisasi skala adalah teknik penstandaran data pada suatu rentang tertentu, umumnya 0-1. Diketahui nilai maksimal dari data fitur sebagai $X_{\max }$ dan nilai minimal dari data fitur adalah $X_{\min }$. Data yang akan dinormalisasi disimbolkan dengan $X$. Nilai hasil normalisasi yang dilambangkan dengan huruf $Y$ didapatkan dari rumus perhitungan normalisasi skala ditunjukkan pada persamaan (2-1).

$$
Y=\frac{X-X_{\min }}{X_{\max }-X_{\min }}
$$




\section{B. Euclidean Distance}

Definisi dari euclidean distance adalah panjang dari garis lurus yang menghubungkan posisi dua buah objek. Secara umum diketahui bahwa jarak terpendek antara dua titik adalah garis lurus antara kedua titik tersebut seperti pada persamaan

$$
\begin{aligned}
d(p, q) & =\sqrt{\left(q_{1}-p_{1}\right)^{2}+\left(q_{2}-p_{2}\right)^{2}+\cdots+\left(q_{n}-p_{n}\right)^{2}} \\
& =\sqrt{\sum_{i=1}^{n}\left(q_{i}-p_{i}\right)^{2}}
\end{aligned}
$$

Di dalam persamaan (2.2), $p$ merupakan array fitur dari gambar tanda tangan di database smartphone, dan $q$ merupakan array fitur dari gambar saat verifikasi tanda tangan. Sedangkan $i$ pada persamaan (2.3) merupakan fitur ke $i$, dan $n$ merupakan jumlah fitur yang dimiliki oleh gambar tanda tangan. Hasil pengukuran euclidean distance adalah $d$.

\section{ANALISIS DAN PERANCANGAN SISTEM}

\section{A. Analisa Permasalahan}

Proses pencatatan kehadiran mahasiswa di Teknik Informatika ITS untuk saat ini masih menggunakan cara manual yaitu menggunakan buku absen dan sering kali terjadi kecurangan yaitu titip absen. Titip absen merupakan kejadian di mana mahasiswa tercatat hadir di daftar hadir kertas tetapi kenyataannya mahasiswa tersebut tidak hadir. Sehingga diperlukan pencatatan kehadiran mahasiswa yang aman dan efisien. Sistem pencatatan kehadiran yang aman dan efisien sejauh ini menggunakan fingerprint. Namun sistem ini membutuhkan biaya yang tidak murah dikarenakan harga alat yang lumayan mahal serta sistem ini tidak dapat dipindah-pindah sehingga setiap ruang kelas harus memiliki alat tersebut.

Dengan memanfaatkan teknologi perangkat bergerak dan internet, diiimplementasikan sebuah aplikasi sistem kehadiran mahasiswa dengan pencocokan tanda tangan. Mahasiswa dapat melakukan presensi pada smartphone masing-masing. Sistem pencocokan tanda tangan dilakukan dengan membandingkan gambar tanda tangan mahasiswa saat melakukan presensi dengan gambar tanda tangan yang telah tersimpan di dalam storage internal smartphone. Dari data tersebut dicari jarak euclidean antara masing-masing fitur pada gambar tanda tangan. Fitur yang digunakan adalah histogram horizontal maksimal, aspek rasio, piksel area dan skewness. Sebelum melakukan ekstraksi fitur dilakukan preprocessing terlebih dahulu untuk menghilangkan noise. Preprocessing yang digunakan adalah $R G B$ to grayscale conversion dan cropping. Verifikasi kehadiran dengan tanda tangan berhasil jika tanda tangan yang dilakukan oleh mahasiswa sesuai dengan gambar tanda tangan yang tersimpan di storage internal smartphone.

\section{B. Diskripsi Umum Sistem}

Hak akses dalam aplikasi ini hanya 1 hak akses, yaitu Mahasiswa. Sistem ini berjalan pada smartphone yang menggunakan REST API dalam mengirimkan hasil validasi kehadiran ke server. Proses dalam sistem sebagai berikut :
1. Tahap masukan yaitu mahasiswa memilih validasi kehadiran tanda tangan dan melakukan presensi kehadiran dengan tanda tangan pada kanvas smartphone. Selain itu masukan yang dilakukan oleh pengguna dalam aplikasi ini adalah mengelola data sampel tanda tangan. Mengelola data sampel antara lain menambah data sampel, mengunduh data sampel ke internal storage smartphone dan menggunggah data sampel ke server.

2. Pada tahap proses yaitu aplikasi mobile melakukan proses simpan data sampel, unggah data sampel tanda tangan dari internal storage smartphone dan unduh data sampel dari server ke internal storage smartphone, serta proses pencocokan tanda tangan.

3. Tahap keluaran yaitu pengiriman status mahasiswa berhasil dalam melakukan presensi kehadiran.

\section{Kasus Penggunaan}

Kasus penggunaan pada sistem terlihat pada Gambar 1



Gambar 1. Diagram Kasus Penggunaan

\section{Perancangan Arsitektur Sistem}

Arsitektur perangkat lunak pada aplikasi ini menggunakan arsitektur 3 lapis yang terdiri dari Data Layer, Bussiness Layer dan Presentation Layer. Data Layer berfungsi untuk menangani basis data aplikasi, Bussiness Layer berfungsi untuk menangani logika aplikasi serta pencocokan tanda tangan. Sedangkan Presentation Layer berfungsi untuk menangani tampilan antarmuka pengguna. Data Layer aplikasi ini menggunakan internal storage smartphone untuk menyimpan data tanda tangan dari pengguna.

\section{E. Perancangan Data}

Perancangan basis data yang akan digunakan untuk menyimpan data tanda tangan dari mahasiswa dan tersimpan di internal storage smartphone. Data tanda tangan berupa image dengan format PNG dengan ukuran panjang 432 piksel dan lebarnya 441 piksel. Gambar 2 merupakan contoh data tanda tangan.

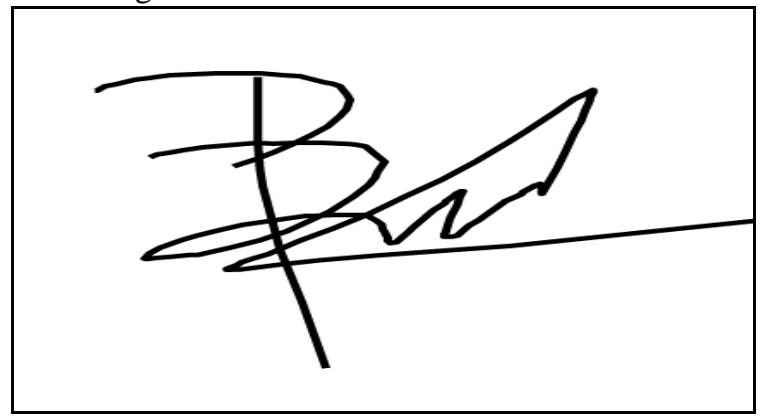

Gambar 2. Perancangan Data 


\section{F. Perancangan Proses}

Alur penggunaan aplikasi validasi kehadiran dengan menggunakan tanda tangan pada sistem kehadiran adalah sebagai berikut :

1. Mahasiswa memilih fitur validasi kehadiran tanda tangan di dalam aplikasi mobile sistem kehadiran mahasiswa.

2. Aplikasi akan melakukan pengecekan jika database internal smartphone kosong maka harus melakukan kelola data tanda tangan terlebih dahulu yaitu memasukkan data tanda tangan sebanyak 5 kali.

3. Setelah proses kelola data tanda tangan selesai, maka dilakukan presensi kehadiran dengan menuliskan tanda tangan di kanvas pada smartphone dengan jari tangan.

4. Proses selanjutnya yaitu pencocokan tanda tangan dengan cara membandingan dataset tanda tangan di dalam database lokal smartphone dengan data tanda tangan yang diperoleh pada saat melakukan presensi kehadiran kemudian menghitung jarak dataset dengan tanda tangan pada saat presensi yang akan dijelaskan pada Gambar 5 .

5. Jika tanda tangan mahasiswa cocok dengan dataset tanda tangan di database internal smartphone maka proses pencocokan gambar tanda tangan berhasil kemudian aplikasi mengirimkan data validasi kehadiran ke database server melalui REST kemudian aplikasi akan menampilkan notifikasi hasil validasi kehadiran.

Dalam sistem yang dikembangkan pada paper [2] gambar tanda tangan yang telah tersimpan di dalam database internal smartphone dilakukan preprocessing terlebih dahulu untuk mendapatkan informasi yang benar pada saat tahap ekstraksi fitur. Preprocessing yang dilakukan yaitu melakukan konversi $R G B$ ke Grayscale dan cropping gambar tanda tangan. Kemudian dilakukan ekstraksi fitur untuk mendapatkan nilai fitur dari masing-masing tanda tangan. Setelah mendapatkan fitur dari gambar tanda tangan di dalam smartphone, maka gambar tanda tangan yang didapat pada saat melakukan verifikasi kehadiran diolah seperti gambar tanda tangan di dalam database. Sehingga masing-masing gambar tanda tangan memiliki fitur masingmasing. Setelah itu dilakukan normalisasi untuk mendapatkan nilai yang standar (rentang nilai sama). Normalisasi yang digunakan dalam aplikasi ini adalah normalisasi skala ( $\min \max$ ) terlihat pada Gambar 4.

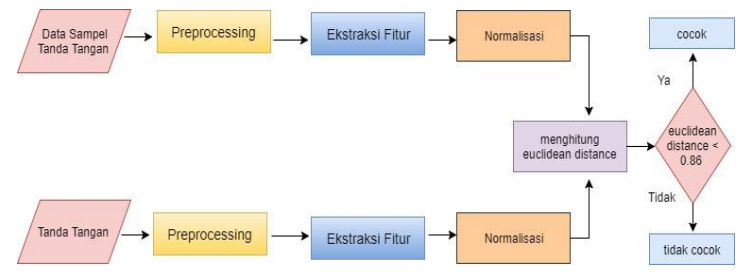

Gambar 3. Diagram Proses Aplikasi Pencocokan Tanda Tangan

$$
\begin{array}{|l}
\text { 1. for } i \leftarrow \theta \text { to jumlah_dataset_tandatangan } \\
\text { 2. for } j \leftarrow \theta \text { to total_fitur } \\
\text { 3. } \\
\begin{aligned}
&\text { fitur_ttd_normalisasi } \leftarrow \text { - } \min (i)) / \max (i)-\min (i)) \\
& \text { 4. } \text { if }(i=\theta) \\
& \text { fitur_ttd_mhs_normalisasi } \leftarrow \text { ( }(\text { fitur_tt }[i]
\end{aligned}
\end{array}
$$

Gambar 4. Pseudocode Normalisasi Skala (Min Max)
Dalam memperoleh hasil bahwa verifikasi kehadiran tanda tangan berhasil/ tidak dilakukan dengan menghitung jarak euclidean (euclidean distance) dari masing-masing tanda tangan di database dengan tanda tangan saat melakukan verifikasi kehadiran. Dari jarak euclidean tersebut dapat ditentukan tanda tangan tersebut cocok atau tidak. Euclidean distance terlihat pada Gambar 5.

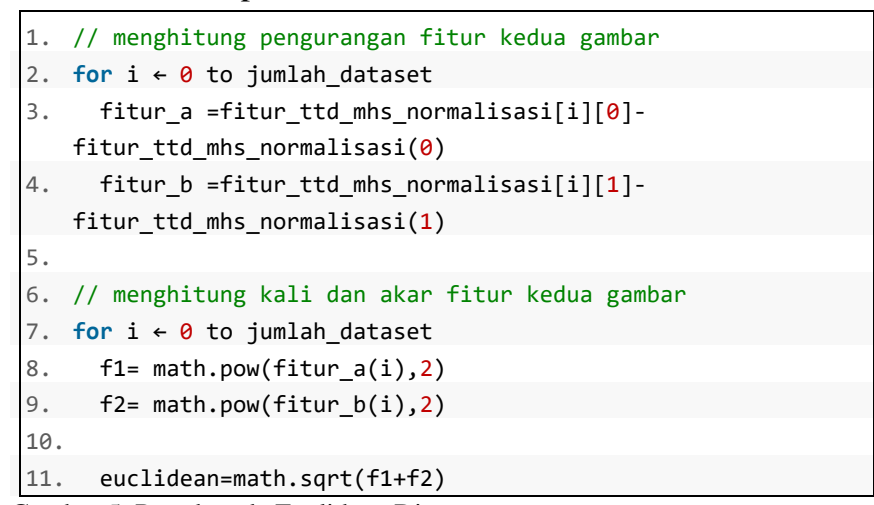

Gambar 5. Pseudocode Euclidean Distance

\section{IMPLEMENTASI}

\section{A. Implementasi Antarmuka}

Contoh implementasi antarmuka aplikasi dapat dilihat pada Gambar 6 dan Gambar 7.

\section{PENGUJIAN DAN EVALUASI}

\section{A. Pengujian Waktu Eksekusi}

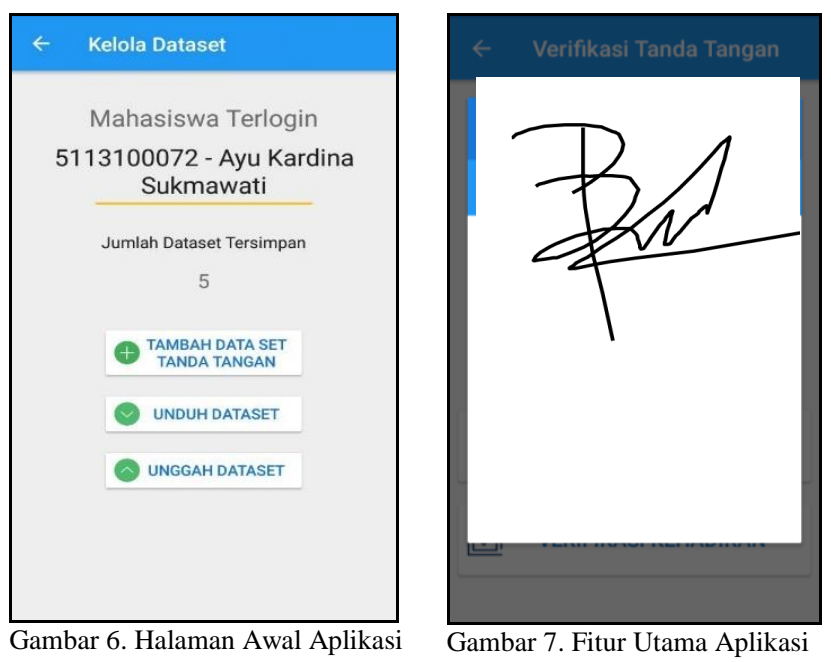

Waktu eksekusi dihitung ketika pengguna memilih tombol kirim (tombol yang digunakan untuk mengecek validasi tanda tangan) sampai muncul notifikasi hasil verifikasi kehadiran. Rata-rata waktu eksekusi yang diperoleh adalah 18.96 detik.

\section{B. Pengujian Keakuratan}

Pengujian keakuratan ini dilakukan untuk mengetahui tingkat keakuratan proses pencocokan tanda tangan pada aplikasi. Pengujian ini dilakukan dengan metode confusion matrix. Akurasi yang didapat adalah $65 \%$.

\section{Pengujian Kebergunaan}

Pengujian dilakukan oleh 30 pengguna yang mencoba menggunakan aplikasi ini. Setelah pengujian selesai 
pengguna diminta untuk mengisi kuesioner yang diberikan untuk mengetahui tanggapan pengguna. Terdapat 8 pertanyaan di dalam kuesioner dengan nilai minimal dari masing-masing pertanyaan adalah 1 dan nilai maksimal adalah 6. Hasil kuesioner adalah 4.70 bahwa aplikasi ini mudah untuk digunakan, 4.70 bahwa tidak sulit memasukkan dataset tanda tangan ke dalam aplikasi, 4.53 bahwa tidak sulit menggunakan fitur presensi kehadiran dengan tanda tangan, 4.26 bahwa hasil presensi kehadiran dengan fitur tanda tangan memiliki hasil yang akurat, 4.40 bahwa presensi kehadiran dengan menggunakan fitur tanda tangan dalam aplikasi ini lebih aman dari kecurangan daripada sistem manual (absen di kertas), dan 4.36 bahwa lebih mudah dan efisien melakukan presensi kehadiran dengan menggunakan fitur tanda tangan dalam aplikasi ini daripada sistem manual (absen di kertas).

\section{KESIMPULAN/RINGKASAN}

Kesimpulan dari pengerjaan aplikasi ini dapat dijelaskan sebagai berikut :

1. Sistem kehadiran mahasiswa melalui pencocokan tanda tangan dapat diakses melalui perangkat mobile berdasarkan hasil uji pada kasus penggunaan Gambar 1.

2. Pencocokan tanda tangan dengan metode normalisasi skala pada fitur gambar tanda tangan dapat digunakan dalam proses validasi kehadiran

3. Penggunaan euclidean distance dapat digunakan dalam proses validasi kehadiran. tanda tangan yang hampir sama namun berbeda terverifikasi oleh aplikasi.

2. Kecepatan ketika melakukan pengecekan tanda tangan dipercepat.

3. Untuk penerapan aplikasi pada Mahasiswa Baru Teknik Informatika ITS 2017 disarankan penambahan dataset tanda tangan melalui hak akses Tata Usaha sehingga aman dari kecurangan dalam memasukkan tanda tangan.

\section{DAFTAR PUSTAKA}

[1]

A. F. Rachman, "Android Kuasai Asia Tenggara, di Indonesia Paling Juara," detikinet. .

[2] N. PUROHIT, SAPNA PUROHIT, and C.S. SATSANGI, "OFFLINE HANDWRITTEN SIGNATURE VERIFICATION USING TEMPLATE MATCHING AND CLUSTERING TECHNIQUE," vol. 2, no. 2, p. 4, Nov. 2014.
Saran dari pengerjaan aplikasi ini dapat dijelaskan sebagai berikut :

1. Batas toleransi aplikasi diperbaiki lagi untuk menghindari 